\title{
КОНСТИТУЦИОННЫЙ ПРИНЦИП ЗАКОННОСТИ УГОЛОВНОГО СУДОПРОИЗВОДСТВА
}

\begin{abstract}
Аннотация: Предметом исследования является содержание конституционного принципа уголовного судопроизводства. Порядок уголовного судопроизводства определялся и определяется только законом: Уставом уголовного судопроизводства в дореволючионной России, Уголовно-прочессуальным Кодексом в Российской Федерации, основанным на Конституции Российской Федерации. Необходимой предпосылкой правильного применения норм уголовно-процессуального права является их правильное толкование (интерпретация), поэтому в статье исследуются способы толкования уголовно-процессуального закона, которые имели место в теории права дореволюционной России и имеют место в теории права современной России. В статье проводится сравнительное исследование содержания принципа законности уголовного судопроизводства, предусмотренного в Уголовно-процессуальных кодексах РФ и Украины, республик Беларусь и Казахстан. Методологическую основу исследования образуют диалектический метод познания действительности, а также частнонаучный метод, методы исторического, сравнительного, логико-юридического, логико-структурного анализа. В статье впервые содержание принципа законности российского уголовного судопроизводства исследуются в связи с содержанием законности по Уставу уголовного судопроизводства, УПК РФ и Украины, республики Беларусь и Казахстан. Обосновывается необходимость введения в УПК РФ в качестве самостоятельных принципов всесторонности, полноты и объективности исследования всех обстоятельств уголовного дела, а также справедливости рассмотрения и разрешения уголовного дела.

Ключевые слова: Конституция РФ, Применение норм права, Толкование (интерпретация) закона, Устав уголовного судопроизводства, Законность, УПК РФ, Порядок уголовного судопроизводства, Справедливость, Аналогия закона, Принципы уголовного судопроизводства.

DOI: 10.7256/1994-1471.2014.4.11101
\end{abstract}

$\mathrm{Y}$ став уголовного судопроизводства был принят в ходе великой отечественной судебной реформы 1864 г., значение и роль которой в государственной жизни России трудно переоценить. Данная реформа была тщательно продумана и подготовлена в отличие от всех наших реформ, в том числе и судебной. Значение Устава уголовного судопроизводства 1864 г. А.ф. Кони определил следующим образом: «Законы о судопроизводстве уголовном, помимо своего значения, как ряд действующих правил об отправлении уголовного правосудия, имеют значение историческое, политическое и этическое. Историческое в смысле показателя путей и степени развития народа к восприятию господствующих форм и обрядов уголовного процесса и усвоение себе связанных с ним учреждений; политическое в смысле обеспечения личных прав и свободы и степени ограничения самовластия органов правосудия и произвола в способах отправления последнего; этическое - в смысле развития правосознания народа и проникновения в процессуальные правила нравственных начал». ${ }^{1}$

Порядок уголовного судопроизводства определялся и определяется только законом: Уставом уголовного судопроизводства в дореволюционной России, Уголовно-процессуальным кодексом в Российской Федерации. Законы необходимы для регулирования взаимоотношений ветвей государственной власти, государства и гражданина, государства и общества. Если политика - это искусство, умение управлять государством, то закон является методом такого управления. Поэтому законность представляет собой прежде всего политикоправовой режим государства.

Верховенство закона устанавливает Конституция Российской Федерации. Статья 1

Кони А.Ф. Введение. Устав уголовного судопроизводства. Систематический комментарий. Вып.1. ст. ст. 1-84. М., 1914. С. 1.

(C) Макарова Зинаида Валентиновна

* Доктор юридических наук, ведущий эксперт, Южно-уральский государственный университет [Lia5565.72@mail.ru]

454000, Россия, г. Челябинск, пр. Ленина, д. 76. 
Конституции РФ провозглашает: «Российская Федерация - Россия есть демократическое, федеративное, правовое государство с республиканской формой правления». Согласно ч.2 ст. 4 Конституции РФ Конституция Российской Федерации и федеральные законы имеют верховенство на всей территории Российской Федерации. В политико-правовой режим законности входят также конституционно-правовые нормы ст. 15, ч.1 ст. 49, ч.2 ст. 50 Конституции РФ, получившие свое закрепление и в УПК РФ.

Несмотря на различные мнения по вопросу о понятии принципов уголовного судопроизводства, большинство ученых понимает под уголовно-процессуальными принципами основные правовые положения, которые выражают сущность уголовного процесса.

Уголовный процесс имеет место только тогда, когда реализуются уголовно-процессуальные нормы, уголовно-процессуальный закон. Поэтому принцип законности является главным, ведущим, основным принципом уголовного судопроизводства.

Законы, определяющие порядок уголовного судопроизводства, указаны в ст. 1 УПК РФ. Это: УПК РФ, основанный на Конституции Российской Федерации, имеющей высшую юридическую силу и прямое действие на всей территории Российской Федерации /ч.1 ст. 15 Конституции РФ/; общепризнанные принципы и нормы международного права и международные договоры, являющиеся составной частью правовой системы Российской Федерации /ч. 4 ст. 15 Конституции РФ/, а также составной частью законодательства Российской Федерации, которое регулирует уголовное судопроизводство. Кроме того, в ч.4 ст. 15 Конституции РФ и в ч.3 ст. 1 УПК РФ указано: если международным договором Российской Федерации установлены иные правила, чем предусмотренные законом УПК РФ, то применяются правила международного договора.

Конституция Российской Федерации устанавливает обязанность органов государственной власти, органов местного самоуправления, должностных лиц, граждан и их объединений соблюдать Конституцию Российской Федерации и законы /ч.2 ст. 15 Конституции РФ/. Согласно ч.2 ст. 1 УПК РФ для судов, органов прокуратуры, органов предварительного следствия и органов дознания, а также иных участников уголовного судопроизводства является обязательным порядок уголовного судопроизводства, установленный УПК РФ. Таким образом, все законы, образующие правовую систему Российской Федерации, обязаны исполняться и применяться в ходе производства по уголовным делам.
Выражением принципа законности являлось и положение ст. 1 Устава уголовного судопроизводства: «Никто не подлежит судебному преследованию за преступление или проступок, не быв привлечен к ответственности в порядке, определенном правилами сего Устава».

Любая деятельность, не соответствующая уголовно-процессуальному закону, не может считаться уголовным процессом. Вне законности нет производства по уголовному делу. Законность - внутреннее, неотъемлемое свойство уголовного судопроизводства; она не может находиться вне его. Уголовный процесс должен быть законным. Только в этом случае возможно выполнение его предназначения: установление уголовно-правового отношения, то есть лица, виновного в совершении преступления, его осуждение и наказание. Поэтому, мягко выражаясь, странным представляется наименование статьи седьмой УПК РФ «Законность ПРИ /выделено нами/ производстве по уголовным делам». Самое распространенное значение предлога «при» - возле, около. Стало быть, законность возле, около производства по уголовным делам, а не в самом производстве по уголовным делам. В любом законе такие двусмысленности не допустимы.

Нормы уголовно-процессуального права реализуются путем их применения, исполнения, соблюдения. Причем применение норм уголовно-процессуального права является обязанностью государственных органов участников уголовного процесса, от которых зависит весь ход производства по уголовному делу и его разрешение. Часть 1 ст. 7 УПК РФ устанавливает, что суд, прокурор, следователь, орган дознания и дознаватель не вправе применять федеральный закон, противоречащий УПК РФ. Следовательно, нормы уголовно-процессуального права имеют преимущество перед нормами права, содержащимися в других федеральных законах. Особое правило предусмотрено частью второй ст. 7 УПК РФ, которое обязывает суд принимать решение в соответствии с УПК РФ, если в ходе производства по уголовным делам установит несоответствие федерального закона или иного нормативно-правового акта УПК РФ.

Необходимой предпосылкой правильного применения норм уголовно-процессуального права является их правильное толкование / интерпретация/. Толкование правовых текстов как индивидуальный интеллектуальный процесс направлен на установление смысла правовых текстов применительно к поведению правовых субъектов /уяснение права/ и на разъяснение этого смысла другим субъектам правовой коммуникации / разъяснение 
права/. ${ }^{2}$ Статьи 12 и 13 Устава уголовного судопроизводства содержали общие правила толкования. Статья 12 Устава уголовного судопроизводства гласила: «Все судебные установления обязаны решать дела по точному разуму существующих законов, а в случае неполноты, неясности или противоречия законов, коими судебное деяние воспрещается под страхом наказания, должны основывать решение на общем смысле законов». Статья 13 Устава уголовного судопроизводства запрещала «останавливать решение суда под предлогом неполноты, неясности противоречия законов. За нарушение сего правила виновные подвергаются ответственности как за противозаконное бездействие власти».

Толкование закона, представляющее собой установление истинного смысла закона, его содержания, необходимо для реализации закона и в первую очередь для его применения, так как, применяя нормы права, государственные органы в уголовном процессе принимают решения, среди которых главным является приговор суда; им уголовное дело разрешается по существу. Для правильного толкования a, следовательно, и для правильного применения законов первостепенное значение имеет определенность правовых норм, что является атрибутом законности и в таковом качестве есть характерная черта любого культурного цивилизованного общества. ${ }^{3}$

В уголовном процессе уясняется смысл не только уголовно-процессуальных норм права, но и уголовно-правовых, а также иных норм права, которые следует применить. Толкование закона является и правом, и обязанностью компетентных органов государства, участвующих в уголовном судопроизводстве, но оно не может создавать новых правовых норм. Это относится также и к судебным прецедентам, которые как установившееся толкование направляет правоприменительную практику к единообразному применению закона, но прецедент не равносилен и не может быть равносильным закону. Суд как орган судебной власти осуществляет правосудие, он не является органом законодательной власти, которая единственная из трех ветвей власти вправе принимать законы. Федеральное собрание - парламент Российской Федерации является представительным и законодательным органом Российской Федерации /ст.94 Конституции РФ/. Суд не может одновремен-

2 См.: Поляков А.В. Общая теория права. СПб., 2004.
С. 804.
3 См.: Аверин А.В. Истина и судебная достоверность / Постановка проблемы. 2-е издание, дополненное. СПб., 2007. C. 158. но создавать законы и применять их, так как в этом случае теряет смысл основа конституционного строя РФ - разделение властей: Государственная власть в Российской Федерации осуществляется на основе разделения на законодательную, исполнительную и судебную. Органы законодательной, исполнительной и судебной власти самостоятельны /ст.10 Конституции РФ/.

Толкование норм права тесно связано с ее субъективным восприятием того, кто применяет данную норму права. Правильность толкования правовой нормы зависит от правосознания, профессионализма, правовой культуры юриста. «...критерием правильности толкования правовой нормы в процессе ее применения служит действительное содержание такой нормы отнюдь не в отрыве от ее субъективного восприятия интерпретатором, а наиболее полное и точное соответствие суждений лиц, толкующих и применяющих правовую норму, выраженной в ней государственной воле». ${ }^{4}$ Толкование норм права, которое имеет место в уголовно-процессуальных решениях, а главное - в приговоре, должно быть обоснованным и мотивированным. Согласно ч. 4 ст. 7 УПК РФ определение суда, постановление судьи, прокурора, следователя, дознавателя должны быть законными, обоснованными и мотивированными. Приговор суда должен быть законным, обоснованным и справедливым /ч.1 ст. 297 УПК РФ/. Не понятно, почему законодатель не установил к приговору такое требование, как мотивированность. К менее значимым процессуальным решениям данное требование имеет место, а к главному решению - приговору суда, которым устанавливается виновность либо невиновность привлеченного к уголовной ответственности лица, законодатель такого требования не предъявляет. Однако в ст. ст. 305 и 307 УПК РФ указывается на изложение мотивов по некоторым вопросам содержания оправдательного и обвинительного приговоров.

В систематическом комментарии Устава уголовного судопроизводства определены цель и задача толкования следующим образом: «Задача толкования: руководствуясь разумом закона, мыслью законодателя, извлечь содержание закона из того изложения, которое дано разъясняемому постановлению законодательной властью, т.к. только мысль законодателя, воплотившаяся в слове закона, составляет закон. Основная цель толкования: постановление решения, соответствующего истинному смыслу

Элькинд П.С. Толкование и применение норм уголовно-процессуального права. М., 1967. С. 59. 
закона / «точному разуму» или «общему смыслу» существующих законов». ${ }^{5}$

Толкование закона необходимо не ради самого толкования, а для принятия в правоприменительной деятельности только таких решений, которые соответствуют значению правовой нормы, выраженной в ней воли законодателя. Для достижения данной цели необходимо раскрыть содержание нормы уголовно-процессуального права, уяснить понятия, в ней содержащиеся и облеченные в словесную форму.

Влад. Набоков различал две формы толкования: 1) основная - /по точному разуму существующих законов/; 2) дополнительная - / по общему смыслу их/. Последняя форма применяется в случае неполноты, неясности или противоречия законов. ${ }^{6}$ Комментарии Влад. Набокова относились к уголовному закону, однако они вполне приемлемы и к уголовно-процессуальному закону, особенно в наше время, когда появляются законы противоречивые, неясные, неполные, когда нет стабильного законодательства. Депутаты развивают бешеную деятельность по приему многочисленных новых законов, бесконечно изменяют и дополняют их. Возмущают заявления депутатов типа: «Мы сейчас быстренько примим закон, в ходе его применения выявим ошибки и недостатки, а затем изменим и дополним закон». Но такой закон - инвалид будет какое-то время действовать /!!!/, в соответствии с ним будут приниматься решения, нередко судьбоносные для граждан, общества, государства. Депутаты забывают, что написать и принять можно любой закон, любую норму права, но каждый закон, каждая норма права должна входить в единую систему законов, пронизанных общим смыслом и общим духом, общим назначением и направленностью.

Ниже приведенное мнение Влад. Набокова о противоречивости законов, их неясности и неполноты представляют интерес для современных юристов и законодателей. ${ }^{7}$ Законы противоречивы, когда из них могут быть выведены два или несколько противоположных решений по одному и тому же вопросу. В этих случаях следует избирать закон, непосредственно относящийся к данному случаю и руководствоваться при этом общими правилами толкования. Однако устранять действительное противоречие путем толкования недопустимо.

Устав уголовного судопроизводства. Систематический комментарий. С. 67.

См.: Набоков Влад. Комментарий к ст. ст. 12, 13 Устава уголовного судопроизводства. Устав уголовного судопроизводства. Систематический комментарий. С. 68.
Закон неясен, когда из его содержания нельзя вывести точный смысл, предполагавшийся законодателем. Цель толкования в данном случае заключается в выяснении этого смысла, опираясь на начала логики, теории права, целесообразности и справедливости.

Закон неполон, когда его буквальный /адекватный/ смысл не совпадает с другими частями законодательства. При толковании такого закона применительно к уголовному процессу следует учитывать основные положения УПК РФ.

В правоприменительной деятельности ее участники могут обнаружить пробелы в законодательстве, для восполнения которых используют аналогию закона и аналогию права. Если Уголовный кодекс РФ запрещает применение аналогии уголовного закона /ч.2 ст. 3/, то в уголовно-процессуальном кодексе РФ подобная нома отсутствует. Применение закона по аналогии должно ограничиваться, однако при существующих пробелах /недостатках, упущениях/ в уголовно-процессуальном законодательстве отказаться от аналогии невозможно. Поэтому в случае применения уголовно-процессуального закона по аналогии следует соблюдать следующие правила: 1) «отношения, к которым применяется норма аналогии, должны быть схожи с уже урегулированными этой нормой отношениями в существенных, а не случайных признаках; 2) необходимо использовать ближайшую аналогию»; 3) аналогия должна применяться в строгом соответствии с назначением уголовного судопроизводства и его принципами; 4) аналогия может иметь место лишь при условии полного и точного соблюдения всех процессуальных прав участников уголовного процесса.

УПК РФ в законность «при производстве по уголовному делу» включает также правило о том, что нарушение норм УПК РФ судом, прокурором, следователем, органом дознания или дознавателем в ходе уголовного судопроизводства влечет за собой признание недопустимыми полученных таким путем доказательств /ч.3 ст. 7 УПК РФ/. Но при особом порядке судебного разбирательства доказательства, собранные на предварительном следствии, не исследуются и не оцениваются, то есть определить, являются ли они допустимыми или недопустимыми, можно только по письменным материалам уголовного дела. Согласно ч.2 ст. 9 УПК РФ никто из участников уголовного судопроизводства не может подвергаться насилию, пыткам, другому жестокому или унижающему человеческое достоинство обращению. Если эта уголов-

\footnotetext{
8 См.: Поляков А.В. Общая теория права. СПб., 2004. C. 799 .
} 
но-процессуальная норма была нарушена на предварительном следствии, в протоколе следственных действий, естественно, данное обстоятельство не отражено, то каким образом судья узнает, что доказательство, полученное таким образом, является недопустимым? Подсудимый может заявить о применении к нему насилия в ходе судебного разбирательства, а свидетель нет, ибо он не вызывается в судебное разбирательство. Получается, что суд при особом порядке судебного разбирательства исходит из непогрешимости органов предварительного расследования, не говоря уже о том, что в данном случае нарушаются конституционный принцип презумпции невиновности и уголовно-процессуальный принцип непосредственности, а приговор не соответствует требованию обоснованности, без которого нельзя судить и о его справедливости. Таким образом, приговор, вынесенный в особом порядке судебного разбирательства, не соответствует двум требованиям, предъявляемым к нему законом.

Часть 2 ст. 9 Уголовно-процессуального кодекса Украины «Законность» устанавливает обязанность прокурора, руководителя органа досудебного расследования, следователя всесторонне, полно и беспристрастно исследовать обстоятельства уголовного производства. Включение данного положения в содержание принципа законности производства по уголовному делу является вполне логичным, так как без всестороннего, полного и объективного исследования всех обстоятельств уголовного дела не может быть речи о законности уголовного процесса. Уголовный процесс, реализуя уголовно-процессуальные нормы, для того и существует, чтобы всесторонне, полно и беспристрастно разобраться в уголовном деле установить и наказать лицо, действительно совершившее преступление. Однако представляется, что значение всестороннего, полного и объективного исследования всех обстоятельств уголовного дела столь велико, что его следует выделить в самостоятельный принцип уголовного процесса. Всестороннее, полное и объективное исследование обстоятельств уголовного дела должно происходить только на основании закона, в строгом соответствии с конституционным принципом законности. Но, не нарушая закон, можно проводить исследование и односторонне, и неполно, и не объективно, то есть по известной ленинской цитате: формально правильно, а по существу издевательство. Делаем все по закону, а осуждаем невиновного и оправдываем виновного. Поэтому всесторонность, полнота и объективность исследования всех обстоятельств уголовного дела должны быть самостоятельным принципом уголовного процесса.
В УПК Республики Беларусь и УПК Республики Казахстан в понятие законности уголовного судопроизводства включено также положение о том, что нарушение закона в ходе производства по уголовному делу недопустимо и влечет установленную законом ответственность и признание решений не имеющими юридической силы /ч.2 ст. 8 УПК Республики Беларусь/, признание недействительными незаконных актов и их отмену /ч.3 ст. 10 УПК Республики Казахстан/. Подобную норму следует включить и в статью 7 УПК РФ. Обязанность государственных органов правильно применять и исполнять законы должна обеспечиваться ответственностью за их нарушение и, что очень важно, признанием незаконных актов не имеющими юридической силы и их обязательной отменой.

Законность тесно связана со справедливостью, поэтому А.Ф. Кони, раскрывая уже отмеченное этическое значение Устава уголовного судопроизводства, указал на проникновение в процессуальные правила нравственных начал. Главным нравственным началом в уголовном процессе является справедливость. Одно из значений понятия правосудия - справедливое решение дела, спора9; правый суд это суд справедливый, содержащий правду. ${ }^{10}$ Таким образом, понятие правосудия /правового суда/ прежде всего предполагает справедливое разрешение уголовного дела. Поскольку правосудие должно осуществляться в строгом соответствии с законом, постольку только законные приговор, решения, действия могут быть справедливыми. Но справедливость и законность - это не одно и то же: если законность - понятие только правовое, то справедливость выражает еще и нравственные представления, чувства, оценки.

Справедливость как общеправовой принцип в первую очередь должен соблюдаться законодателем, законодательной властью. «... в содержательном смысле справедливость в рамках концепции верховенства права выполняет функцию «критерия качества» позитивного законодательства, его соответствия идее права». ${ }^{11}$ Чем справедливее законы, тем успешнее они будут применяться и исполняться.

В УПК РФ требование справедливости предъявляется к приговору суда /ч.2 ст. 297, ст. ст. $383,389^{15} /$. В ч. 2 ст. 6 УПК РФ указывается на справедливое наказание. Согласно ст. 332 УПК РФ присяжный заседатель в присяге торжест-

\footnotetext{
См.: Ожегов С.И. Словарь русского языка. М., 1989. C. 575 .

10 См.: Там же.

11 Пресняков М.В. Конституционная концепция справедливости // Правоведение. 2011. №6. С. 127.
} 
венно клянется разрешать уголовное дело как свободный гражданин и справедливый человек. В соответствии со ст. $389^{28}$ УПК РФ в апелляционном приговоре, определении, постановлении указываются основания, по которым приговор признается законным, обоснованным, справедливым. Таким образом, российское уголовно-процессуальное законодательство ориентировано не только и не столько на так называемую процедурную справедливость, сколько на результат - справедливое разрешение уголовного дела. Именно справедливое разрешение уголовного дела, справедливые решения по нему и в первую очередь, и главным образом справедливый приговор, оказывают воспитательно-профилактическое воздействие на общество и отдельных граждан. Высший смысл, высшее предназначение уголовного судопроизводства - справедливое разрешение уголовного дела в результате его справедливого расследования и рассмотрения в строгом соответствии с законом.

\section{Библиография}

1. Аверин А.В. Истина и судебная достоверность (Постановка проблемы): 2-е издание, дополненное. - СПб., 2007.

2. Кони А.Ф. Введение. Устав уголовного судопроизводства. Систематический комментарий: Вып.1. ст. ст. 1-84. - М., 1914.

3. Набоков Влад. Комментарий к ст. ст. 12, 13 Устава уголовного судопроизводства. Систематический комментарий: Вып.1. ст. ст. 1-84. - М., 1914.

4. Ожегов С.И. Словарь русского языка. - М., 1989.

5. Пресняков М.В. Конституционная концепция справедливости: Правоведение. 2011. №

6. Элькинд П.С. Толкование и применение норм уголовно-процессуального права. - М., 1967.

\section{References}

1. Averin A.V. Istina i sudebnaya dostovernost' (Postanovka problemy): 2-e izdanie, dopolnennoe. SPb., 2007.

2. Koni A.F. Vvedenie. Ustav ugolovnogo sudoproizvodstva. Sistematicheskii kommentarii: Vyp.1. St.st. 1-84. - M., 1914.

3. Nabokov Vlad. Kommentarii k st.st. 12, 13 Ustava ugolovnogo sudoproizvodstva. Sistematicheskii kommentarii: Vyp.1. St.st. 1-84. - M., 1914.

4. $\quad$ Ozhegov S.I. Slovar' russkogo yazyka. - M., 1989.

5. Presnyakov M.V. Konstitutsionnaya kontseptsiya spravedlivosti: Pravovedenie. 2011. №

6. El'kind P.S. Tolkovanie i primenenie norm ugolovno-protsessual'nogo prava. - M., 1967. 